\title{
Some Remarks about Linguistic Expressions in Writings about Ethnicity and Conflict: The Case of Yugoslavia
}

\author{
Sreca Perunovic ${ }^{1}$
}

The paper suggests that the extensive and frequently controversial literature about the 1990s Yugoslav crisis can be viewed as an opportunity for reflection on the discourse itself. The article examines the role of ethnonyms and some related linguistic expressions used in scholarly and other writings about the demise of Yugoslavia. The examination has shown that the linguistic simplifications covering different social groups with umbrella expressions such as the Croats, the Serbs, etc. may constitute a source of puzzlement and even inaccuracy. It is argued that ethnic studies in general would gain much by paying more attention to nuances than by relying on ethnonyms as if they were clear-cut concepts. [Article copies available for a fee from The Transformative Studies Institute. E-mail address: journal@transformativestudies.org Website: http://www.transformativestudies.org (C2011 by The Transformative Studies Institute. All rights reserved.]

KEYWORDS: Yugoslavia, Ethnonyms, Linguistic Expressions, Ethnic Conflict, Ethnic Groups, Academic Discourse, Yugoslav Wars.

\footnotetext{
${ }^{1}$ Sreca Perunovic, Ph.D., is a sociologist working on ethnicity, interethnic relations, ethnic conflict and nationalism, focusing on Yugoslavia. She is an Assistant Professor LaGuardia Community College, CUNY at the Social Science Department. She received her Ph. D. in Sociology from the University of Zagreb, Croatia/Yugoslavia. Prior to coming to LaGuardia, she has taught at John Jay College, New School University, and was a visiting scholar in the Ph.D. Program in Anthropology at the Graduate Center of the CUNY. She has published articles in Journal of International Law and Politics, European Journal of Intercultural Studies, and Journal of Ethnic Studies, among others. Address correspondence to: Sreca Perunovic, LaGuardia Community College, 255 W. 94. St., New York, NY 10025; e-mail: sperunovic@lagcc.cuny.edu.

Acknowledgement of research support: This research has been supported by PSCCUNY (grant number 60114-39 40 PSCOOC-40-245).
} 